\title{
Microbiological Assessments Of Raw Cow Milk, 'Nono' And Loca lly Fermented Cheese, Sold At Different Markets In Bida, Bida L GA, Niger State, Nigeria.
}

\author{
Barnabas, B. B.; Ayodele, O. P.; Gana, J.; Jiya, A. G. and Igheghe, F. \\ Science Laboratory Technology Department, Federal Polytechnic, P. M. B. 55, Bida, Niger State, Nigeria.
}

\begin{abstract}
Raw Cow Milk, 'Nono', And Locally Fermented Cheese Samples Were Purchased From Three Diffe rent Markets In Bida Metropolis, Bida L.G.A. For Microbiological Analysis. The Results Showed That Samples Of Raw Cow Milk Bought From The Post Office Market Had The Highest Microbial Load Of 7.0 X $10^{6} \mathrm{Cfu} / \mathrm{Ml}$. Escherichia Coli, Salmonella Spp., Staphylococcus Spp. Lactobacilus Spp And The Fungus Aspergillus Spp Wer e Dominant Microorganisms Isolated From All The Samples. Ph Range Of 5.8-6.2 And Temperature Range Of $30.3-31^{\circ} \mathrm{C}$ Were Observed In All The Samples During The Experimental Work. The Presence Of E. Coli, Salm onella, Spp. And Staphylococcus Spp. Are Indications Of Contamination Possibly As A Result Of Poor Sanitary Conditions And Poor Handling By The Producers.
\end{abstract}

Key Words: Raw Cow Milk, Microbiological Analysis, Contamination, Poor Sanitary Practices.

\section{Introduction}

Milk is an opaque liquid produced by the mammary glands of female animal including man. It provides the primary source of nutrition for newborn mammals before they are able to digest other types of food. The ear ly lactation milk is known as colostrums and carries the mother's antibodies to the baby. It can reduce the risk of many diseases in the baby. The exact component of milk varies in species, but it contain significant amount of $\mathrm{s}$ aturated fat, protein, calcium as well as vitamin $\mathrm{C}$.

Raw milk is defined as unpasteurized or unhomogenized milk. Human consumption of raw and unpaste urized milk dates back to periods before the industrial revolution (Bren, 2003).

Common bacterial flora of raw milk include: the Lactic Acid Bacteria (LAB) which includes: Lactobac illus lactis, L. bulgaricus, L. helvericus), Leuconostoc species Streptococcus thermophiles, S. lactis, S. cremoris, as well as Propionic Acid Bacteria (PAB), (Congan, 1995). Most coliforms inhabit the intestines of warm - bloo ded animals and are normally shed along with their faeces to living environments. Many other foodborne pathog ens equally migrate from faecal contaminations. The process of milk production, (fermented milk products incl usive) by Nomadic Fulani women gives lots of concern because of the unhygienic practices, the quality of the w ater they use, the feeding method for the cows and above all the processing environment. Therefore, it is essenti al that strict sanitary practices be followed to minimize the risk of infection to people consuming raw milk produ cts (Chan et al., 2007).

Cheese on the other hand is made from milk of cow, buffalo, goat or sheep by coagulation of the liquid medium after undergoing the first stage of acidification by LABs (Jenkins, 1996). Cheese is very valuable for its portability, long shelf life and content fat, protein, calcium and phosphorus. It is a more compact form of nutriti on than the milk from which it is obtained (National Dairy Council, 2005).

Cheese is a very popular food called 'Wara' in Nigeria and largely consumed under different names in other West African countries including the Republic of Benin. Cheese making involves the process of separating the protein content from the water medium and the addition of Rennet which causes the milk protein to clump o $r$ coagulate when subjected to pasteurization to ultimately form a semi - firm gel or curds. The extent of microor ganisms inactivation depends on the combination of temperature holdings. Non - crude cultured milk also know $\mathrm{n}$ as 'Nono' by the Fulanis and Hausa speaking tribes of Nigeria is a fermented dairy product made from raw mi $1 \mathrm{k}$ brought about by a mixed culture of microorganisms.(American Dairy Science Association, 2003). Healthy d airy cattle are considered a reservoir base for several most important foodborne human disease pathogens in thei r milk.

The study aims at microbiological analysis of raw cow milk, cheese and 'Nono' milk products sold in Bida Niger State; to isolate the contaminating bacteria, to assess the antibiotic sensitivity of the possible bacteria isolates and to so as to ascertain the safety of these products for consumption. 
Source of Materials

\section{Materials And Methods}

The raw milk 'Nono' and cheese samples were collected in sterile plastic containers from various Fulani hawker $\mathrm{s}$ in the Small market, Post Office market and Modern market in Bida. Both the $\mathrm{pH}$ and Temperature $\left({ }^{\circ} \mathrm{C}\right)$ of the milk medium were immediately determined.

\section{Microbiological Analysis}

\section{Total viable count (TVC) (bacteria)}

The total viable counts (TVC) of each of the samples were determined using the pour plate technique. $0.1 \%$ pep tone water and nutrient agar were used to prepare the serial dilution technique. Contents that developed in each plate were counted and recorded as Colony forming units $(\mathrm{Cfu} / \mathrm{ml})($ Cruikshank et al., 1975). The media used fo $\mathrm{r}$ bacterial isolation were MacConkey agar, Blood agar, Chocolate agar and de Man Rogosa sharp agars

\section{Total viable count (TVC) (fungal)}

Fungal counts were determined using Potato Dextrose Agar (PDA) (Biotech, UK) to which Chloramphenicol wa $\mathrm{s}$ added prior to sterilization in order to inhibit any bacterial growth. The colonies that developed were counted and recorded as Colony forming units $(\mathrm{Cfu} / \mathrm{ml})$ after 3-7 days or incubation. The cultural characteristics of disti ct colonies of pure isolates of mould were determined according to standard microbiological procedures. For en umeration of coliform bacteria, standard microbiological procedures described by Food and Agriculture Organiz ation were employed (FAO, 1979). The biochemical reactions of the isolates and sugar fermentation reactions $b$ $\mathrm{y}$ the microorganisms were determined for final confirmation of genera of the organisms using Bergeys Manual of Determinative Bacteriology (Smeath et al., 1986). Antibiotic sensitivity testing was carried out on all isolates using commercial discs on dry, sterile nutrient agar plate to observe the zones of inhibition by the antibiotics ( $\mathrm{N}$ nochiri, 2000).

\section{Result:}

Table 1: Physical and chemical quality of Raw Milk 'Nono', and Cheese bought from various markets in Bida

\begin{tabular}{lll}
\hline Samples & Temperatures $\left({ }^{0} \mathrm{C}\right)$ & $\mathrm{P}^{\mathrm{H}}$ \\
\hline Small Market & & \\
$\mathrm{A}_{1}$ & $30.3 \pm 0.57$ & $5.8 \pm 0.08$ \\
$\mathrm{~A}_{2}$ & $30.3 \pm 0.57$ & $5.9 \pm 0.08$ \\
$\mathrm{~A}_{3}$ & $30.3 \pm 0.57$ & $5.8 \pm 0.08$ \\
Post Office Market & $31.6 \pm 0.58$ & \\
$\mathrm{~B}_{1}$ & $31.6 \pm 0.58$ & $6.0 \pm 0.15$ \\
$\mathrm{~B}_{2}$ & $31.6 \pm 0.58$ & $6.0 \pm 0.15$ \\
$\mathrm{~B}_{3}$ & $31.0 \pm 0.00$ & $6.0 \pm 0.15$ \\
Modern Market & $31.0 \pm 0.00$ & $5.9 \pm 0.08$ \\
$\mathrm{C}_{1}$ & $31.0 \pm 0.00$ & $5.9 \pm 0.08$ \\
$\mathrm{C}_{2}$ & & $5.9 \pm 0.08$ \\
$\mathrm{C}_{3}$ & & \\
\hline
\end{tabular}

Table 2: Microbiological Quality of Raw Milk,' Nono', and Cheese bought from various markets in Bida

\begin{tabular}{|c|c|c|c|c|c|c|c|}
\hline \multirow[t]{2}{*}{ Samples } & \multirow[t]{2}{*}{ TVC (cfu/ml) } & \multirow[t]{2}{*}{$\mathrm{YC}(\mathrm{cfu} / \mathrm{ml})$} & \multirow[t]{2}{*}{$\mathrm{MC}(\mathrm{cfu} / \mathrm{ml})$} & \multicolumn{3}{|c|}{ Dilution/No of Positive Tubes } & \multirow{2}{*}{$\begin{array}{l}\text { MPN/100ml. } \\
\text { s et al., (1987) }\end{array}$} \\
\hline & & & & $1^{-1}$ & $10^{-2}$ & $10^{-3}$ & \\
\hline$A_{1}$ & $3.7 \times 10^{6} \pm 2.6 \times 10^{6}$ & $3.2 \times 10^{2} \pm 1.3 \times 10^{2}$ & $5.0 \times 10^{2} \pm 0.5$ & 2 & 3 & 2 & 44 \\
\hline $\mathrm{A}_{2}$ & $2.5 \times 10^{6}+2.0 \times 10^{6}$ & $3.1 \times 10^{2}+1.2 \times 10^{2}$ & $3.0 \times 10^{2}+0.2$ & 3 & 1 & 3 & 160 \\
\hline$A_{3}$ & $1.3 \times 10^{6} \pm 1.0 \times 10^{6}$ & $2.7 \times 10^{2} \pm 1.0 \times 10^{2}$ & $<10 \pm 0$ & 3 & 2 & 2 & 210 \\
\hline $\mathrm{B}_{1}$ & $2.2 \times 10^{6}+1.8 \times 10^{6}$ & $3.1 \times 10^{2}+1.2 \times 10^{2}$ & $<10+0$ & 3 & 1 & 2 & 120 \\
\hline $\mathrm{B}_{2}$ & $7.0 \times 10^{6} \pm 4.6 \times 10^{6}$ & $1.9 \times 10^{2} \pm 1.0 \times 10^{2}$ & $<10 \pm 0$ & 3 & 3 & 1 & 460 \\
\hline $\mathrm{B}_{3}$ & $1.6 \times 10^{5}+1.5 \times 10^{5}$ & $3.4 \times 10^{2}+1.3 \times 10^{2}$ & $<10+0$ & 3 & 3 & 2 & 1100 \\
\hline $\mathrm{C}_{1}$ & $4.2 \times 10^{6} \pm 2.8 \times 10^{6}$ & $1.5 \times 10^{2} \pm 1.0 \times 10^{2}$ & $<10 \pm 0$ & 3 & 0 & 2 & 64 \\
\hline $\mathrm{C}_{2}$ & $3.6 \times 10^{5} \pm 2.6 \times 10^{5}$ & $2.7 \times 10^{2} \pm 1.0 \times 10^{2}$ & $<10 \pm 0$ & 3 & 1 & 1 & 75 \\
\hline $\mathrm{C}_{3}$ & $1.8 \times 10^{5} \pm 1.3 \times 10^{5}$ & $1.5 \times 10^{2} \pm 1.0 \times 10^{2}$ & $<10 \pm 0$ & 3 & 1 & 3 & 160 \\
\hline
\end{tabular}

Each value is the mean \pm Standard Deviation (SD) of three determinations.

$\mathrm{TVC}=$ Total Viable Count

$\mathrm{YC}=$ Yeast Count

$\mathrm{MC}=$ Mould Count

$\mathrm{CFU}=$ Colony Forming Unit 
Microbiological Assessments Of Raw Cow Milk, 'Nono' And Locally Fermented Cheese, .....

Table 3: Antibiotic Sensitivity testing of Nono, Raw Milk and Cheese bought from various markets in Bid aKey

\begin{tabular}{|c|c|c|c|c|c|c|c|c|c|c|c|c|}
\hline \multirow[t]{2}{*}{ Codes } & \multicolumn{12}{|c|}{ Antibiogram } \\
\hline & TA & Pet & Cpx & $\mathrm{Au}$ & Gn & $\mathrm{S}$ & Cep & $\mathrm{Na}$ & Sxt & An & $\operatorname{Pr}(\%)$ & $\operatorname{Ps}(\%)$ \\
\hline 111 & $\mathrm{R}$ & $\mathrm{S}^{+}$ & $\mathrm{R}$ & $\mathrm{S}^{+++}$ & $\mathrm{S}^{++}$ & $\mathrm{S}^{+}$ & $\mathrm{R}$ & $\mathrm{R}$ & $\mathrm{S}^{+}$ & $\mathrm{R}$ & 50 & 50 \\
\hline 112 & $\mathrm{~S}^{+}$ & $\mathrm{R}$ & $\mathrm{S}^{+}$ & $\mathrm{S}^{+++}$ & $\mathrm{S}^{++}$ & $\mathrm{S}^{+}$ & $\mathrm{S}^{++}$ & $\mathrm{R}$ & $\mathrm{R}$ & $\mathrm{S}^{+}$ & 30 & 70 \\
\hline 113 & $\mathrm{~S}^{+}$ & $\mathrm{S}^{++}$ & $\mathrm{R}$ & $\mathrm{S}^{++}$ & $\mathrm{S}^{++}$ & $\mathrm{S}^{+}$ & $\mathrm{R}$ & $\mathrm{R}$ & $\mathrm{S}^{+}$ & $\mathrm{S}^{+}$ & 30 & 70 \\
\hline 114 & $\mathrm{~S}^{+}$ & $\mathrm{S}^{++}$ & $\mathrm{R}$ & $\mathrm{S}^{+++}$ & $\mathrm{S}^{++}$ & $\mathrm{S}^{+}$ & $\mathrm{S}^{+}$ & $\mathrm{R}$ & $\mathrm{R}$ & $\mathrm{S}^{++}$ & 30 & 70 \\
\hline 115 & $\mathrm{R}$ & $\mathrm{S}^{++}$ & $\mathrm{R}$ & $\mathrm{S}^{++}$ & $\mathrm{S}^{++}$ & $\mathrm{S}^{+}$ & $\mathrm{S}^{+}$ & $\mathrm{R}$ & $\mathrm{R}$ & $\mathrm{S}^{+}$ & 40 & 60 \\
\hline
\end{tabular}

TA - TARVID, PEF - PEFLACINE, CPX - CIPROFLOX

AU -AUGMENTIN, GN - GENTAMYCIN, S -STREPTOMYCIN

CEP - CEPOREX, NA - NALIDIXIC ACID, SXT - SEPTRIN

AN -AMPICILIN

$\mathrm{R}$ - RESISTANCE

S - SENSITIVE

PR - PERCENTAGE RESISTANCE $=$ No. of $\mathrm{R} \quad \mathrm{x} \quad 100$

No. of antibiotics

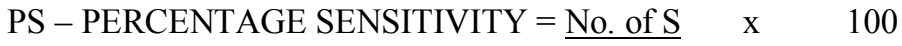

No. of antibiotics

$0-2 \mathrm{~mm}=\mathrm{S}^{+}$

$2-4 \mathrm{~mm}=\mathrm{S}^{++}$

$4-6 \mathrm{~mm}=\mathrm{S}^{+++}$

\section{Physicochemical properties of the collected samples}

\section{Discussion}

The temperature of the samples from the three markets ranged on the average from $30.3+0.5-31.6 \pm 0.6$ while $t$ he $\mathrm{pH}$ of the medium ranged between 5.8-6.0 \pm 0.2 respectively. From Table 2, we observed that all the samples collected from small market showed very high Total Viable Count for bacteria with the highest $\left(3.7 \times 10^{6} \mathrm{Cfu} / \mathrm{ml}\right)$

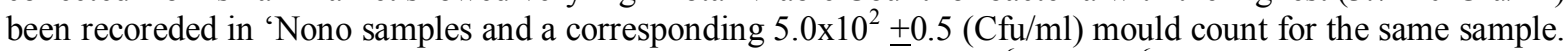
Samples from the Post Office Market has Total Viable Count of $7.0 \times 10^{6} \pm 4.6 \times 10^{6}$ for bacteria which was record ed in raw cow milk with a corresponding $<10 \pm 0$ mould count for the same sample. Samples from the Modern Market have the highest Total Viable Count of $4.2 \times 10^{6} \pm 2.8 \times 10^{6}$ in 'Nono' and a corresponding low mould coun ts for the same sample. The result showed that all the samples have very high bacteria loads for 'Nono' and corr espondingly low mould counts except the samples taken from the Small Market which recorded the highest bact eria load of $7.0 \times 10^{6} \pm 4.6 \times 10^{6}$ while the least was recorded in samples taken from the Modern Market. All the che ese samples from the three markets have relatively low bacterial loads than the other two milk products from the same market.

Lactobacillus specie, Escherichia coli, Staphylococcus spp, Salmonella species were the bacteria of interest freq uently isolated from all the samples. ASpergillus nidulans and A. niger were also common moulds isolated from the samples. The presence of some of the microorganisms are indications of contamination during the milking, preparation, storage and marketing processes due to very poor sanitary practices by the Fulani handlers.

The frequent occurrence of E. coli for example, which is faecal coliform in most of the samples, is an indication of poor sanitary habits as evidenced by the way and manner the beverages are produced and marketed. Such poo $\mathrm{r}$ sanitary conditions could be responsible for the increase in the microbial load as evidenced in this investigation . The same argument can be advanced for the presence of Salmonella spp and Staphylococcus spp, as a result of poor handling practices during preparation and selling as Staphylococcus spp, are normal flora of the skin, hand $\mathrm{s}$ and udder of cow (Jay, 1986). Fungi generally, are the main agent that causes food spoilage. They cause off $-\mathrm{f}$ lavor in milk and milk products.

The $\mathrm{pH}$ values of the samples $(5.8-6.2)$ are indications of the souring ability of Lactic Acid Bacteria to inhibit $\mathrm{t}$ he growth of other microorganisms particularly pathogenic organisms. Ideal antibiotic therapy is based on deter mination of the etiological agents. The effectiveness of individual antibiotic varies with the location of the infect ion and the ability of the bacteria to resist or inactivate the antibiotic.

\section{Conclusion}

From Table 3, we observed that bacteria isolates from Small Market showed maximum sensitivity (50\%) to Aug mentin, Gentamycin and Septrine. While those from Post Office Market showed similar sensitivity but at a high er percentage $(70 \%)$ and producing a zone of inhibition of between $4-6 \mathrm{~mm}$ in the listed antibiotics above. Wit $\mathrm{h}$ little understanding and health education on basic hygiene practices on the part of the Fulani hawkers of these dairy products, the rate of contamination and consequent exposures of the consumers will be minimized. Govern ment at all levels must as a matter of urgency, provide portable water for rural community for the preparation of 
these beverages.

\section{References}

[1] American Dairy Association (2003). Farm management and milking practices associated with the presence of Listeria monocytogenes in New York State dairy herds prev.vet med. (51) $63-73$.

[2] Bren, Linda. "Got Milk? Make sure its pasteurized". Michigan Department of Agriculture, USA.

[3] Chan, H, Kahan, Z., Hakkak, M. and Ivany, K. (2007) Role of diet in prostrate cancer development and progression (23): 152 160 .

[4] Congan, T., (1995). Flavour production by Lactic Acid Bacteria Tropical applied bacteriology symposium supplementary (79): $495-645$.

[5] Cruickshank, R., Dughid Y.P., Marrimon, B.P. and Swain, R.H.A. (1975). Medical Microbiology (12 ${ }^{\text {th }}$ ed). Church hill living stone, Edinburgh, London (2): 565.

[6] Food and Agricultural Organisation (1979). Manual of Food quality control (4) Microbiological analysis. Rome, Italy Pp. 1 - 12.

[7] Jay, T.M. (1986). Modern food Microbilogy ( $3^{\text {rd }}$ ed.). Van Nastrian Reinhold company New York, Pp. 242 - 243

[8] Jenkins, Steven (1996). Cheese Primer. Workman publishing company ISBN 0-89480-762-5

[9] National Dairy Council (2005). Practical food safety interventions for dairy production. New York

[10] Nnochin, R. (2000). The changing patterns of antibiotic resistance and pathogenic bacterial isolates as indicators of drug abuse in middle Africa. In proceedings of 1973 annual scientific conference of East Africa medical research council Pp: $4-6$

[11] Smeath, P.H.A, nair, N.S., Sharpe, N.E. and Holf, Y.G. (1986). Bergey's manual of systemic Bacteriology (2), Williams and wilkins Baltimare Press. 